\title{
Votive altars: domestic signals to inhabit the Sacred
}

\author{
Claudio Gambardella ${ }^{1}$, Valentina Sapio ${ }^{1}$ \\ ${ }^{1}$ Dipartimento di Architettura e Disegno Industriale, Universita` degli Studi della Campania,
}

Email: claudio.gambardella@unicampania.it,Email:valentina.sapio@unicampania.it

\begin{abstract}
"Sacred" is an Indo-European word meaning "separate". The Sacred, therefore, [ . . is] a quality that is inherent in that which has relation and contact with powers that man, not being able to dominate, perceives as superior to himself, and as such attributable to a dimension [... ] thought however as "separate" and "other" with respect to the human world » Galimberti, (2000). The so-called votive altar, autonomous or attached to a major building often present in the Mediterranean countries, belong to the dimension of the Sacred.

Votive altars - present in an old neighborhood of peasant origin in the suburbs of Naples called Ponticelli - are almost always placed in the interstices between street and courtyard (a self-built residential typology modeled over time by the inhabitants and which often forms the matrix of many neighborhoods popular Neapolitan). They keep and exhibit little sculptures and drawings of Jesus, Madonnas, and Saints of the Catholic religion, mixed with ancestors portraits and photos of relatives dead of the inhabitants, drawing on the ancient domestic cult of the Romans of Lari and Penati; it is certainly not a consciously cultured reference, but a mysterious "feeling" that is common among primitive and popular cultures and that unravels through the centuries unscathed. Placed at the entrance of the living space, the altar expresses the sign of a difference, of a territorial change, separates "ours" from "yours", welcomes, does not reject, but marks an open and inclusive threshold.

With the paper, we want to study this phenomenon of "primitive" culture and not regulated by laws, a mix of diffuse sacredness and popular magic, deepening the "design" aspects of it, building an abacus in which to highlight potential and free references to the visual arts of these "design works without designers", and finding out new signs of the Sacred in the City in our time.
\end{abstract}

(c) 2019 The Authors. Published by IEREK press. This is an open access article under the CC BY license (https://creativecommons.org/licenses/by/4.0/).

\section{Keywords}

Sacred; Tradition; Interior Design; Votive Altars; Culture

\section{Introduction}

"I would rather believe this. It is man's measure. Full of merit, but poetically, man dwells on this earth. But the Shadow of the night with the stars, if I could say it this way, is not purer than man, who is called an image of God" Heidegger (2008) . Martin Heidegger, in Poetically man dwells, Essays and Dialogues of 1976, expresses himself in this way. The sense of dwelling is eternally linked to the main vector of original nostalgia. Both the memory of locations preservation, and the possibility to dwell them as home, to tame them the sense that man unconsciously feels it is exactly to dwell. 


\section{The sense of dwelling}

If the root habitus connects to the habit, the things of everyday, the name of the Goddess of dwelling and of the home is Vesta in the Roman religion, identified with the Greek goddess Hestia, that derives from the Indo-European vas, to dwell, defined by Ovid as "Nothing else than live fire". Once the idea of home went around to the concept of hearth sharing between its inhabitants. To dwell is to take care of own space, to be related with the space, to fill the artificial gap in the project, to build and to dwell giving to this latter a prevalent holiness eventually.

From this perspective the act of building-erecting becomes as the act of farming in the agricultural field, by taking care of the terrain and the nature in as far as it changes without subjugation pretensions.

The farmer's time, actually, is beaten by birth and death, sowing and harvest, hopes, disappointments, fairs, successes, survivals. The decisive relation between dwelling, religiosity and natural cycles expresses itself in a mythic system where the seasonal experience of work and wait for the results is narrated as an alternation of death and of life, they are never predominant and independent reciprocally.

Ernesto De Martino, an anthropologist, historian of religion and Italian philosopher, in his essay Sud e magia, he analyses the rapport between the places of the dwelling, religious culture in a mystical sense of rural populations of the south of Italy. The significant expedient that links these populations, about the holy and the location, is the ceremonial magic.

"In the magic-religious civilization of so-called primitive or ancient world as well as in the folklorist wrecks of the most rude ceremonial magic, unintentional fascination and intentional charm, witchcraft and spirits and demons hidden danger, possession and exorcism, talisman and actions against charm, inspection of signs and divinatory activities belong to the same ideological order, the importance of which and role in the overall context of religious life of a specific civilization or of a specific epoch has to be fixed from time to time”. E (2013) (De Martino)

The fascination is the topic of the ceremonial magic, it suggests a psychic condition of obstacle and restriction, and at the same time a kind of domination leaves with no margin the autonomy of the person, his decision-making power and choice. From the analysis of De Martino's Essays it is proved that fascination, possession, exorcism, charm and actions against charm of every civilization, they have to be led back to the daily life uncertainty, to the big power of negative and the lack of action perspective realistically orientated to face critical moments of the existence and above all to the psychological reflection of being overcome with its related psychological rescues. Under these circumstances the magical moment, seen as a holy artifice, becomes very important, because it satisfies the psychological reintegration need through mythical-ritual techniques, allowing in this way to face in a protected regime the power of negative in the history.

\section{The doorstep as a place}

If the men's folklorist rituals protect the social and individual life evolution, the place, as environment of production and re-production of work, family, community, it is protected by powerful symbols and appropriate ritual conduct: the presence of votive aedicules and symbologies near the entrance of homes it is the end of a popular religious culture handed down through the ages.

The role of the doorstep has an important meaning, it shows the original vocation of the architectonic space: to receive man and put him in connection with the world. "It points out that the physical limits of the dwelling built according the art rules, they aren't conceived for the exclusive closure, but always for the inclusive opening. The doorstep doesn't have to isolate but to connect two spaces, establishing between them a reciprocity and comple- mentary relations; to discern them and not separate them; to reveal the different identity even if in the common nature of built space. As transition and access space it organizes to the meeting, hospitality and discovery". M. and V (2016) (Agostino Bossi).

The stabilization of the value of the doorstep appears, in the popular culture, through symbols, temples or votive aedicule, collocated in a strategic way with respect to the dwelling or urban fabric. The position of these artifices doesn't have a decorative function but receives prayer times or rituals linked to superstitious behaviours happened 
near the entrance. The entrance was as a location of goodness presences with apotropaic-safeguard function. Actually, there are so many behavioural symbolisms that make the doorstep as a place to protect and from which one had to protect, as Lucio Apuleius, the Latin writer of II century, remembers us in his essay "The metamorphosis". Across mysterious worship and vicissitudes that create an allegorical allusion to the difficulties that the soul has to face as test bench to get faith and purity, the presence of votive aedicule and symbols provides certainty of faith and confidence in the afterlife.

\section{The origins: the Lares Familiares}

Before trying to track a possible identity line purely popular of this architectural production and minor artistic, both with its relation with cultured art, and in its dialectic with the official religiousness, and in relation to the rural community which it was expression, especially in the reality of Campania and south of Italy, it is necessary to take a step back through the ages and mention Lares Familiars.

To realize temples or votive aedicule, the most utilized raw materials were terracotta, glass, plaster and wood.

The Lares and the Penus (respectively from Latin "hearth" and "everything men eat") were religious figures during Roman times, they represented the protective spirits of the deceased ancestors and the protective spirits of a family. According to the Roman customs, they kept vigil on the smooth running of family, of the property or the activity in general, adorned with effigies by a statuette made of wax. Inside the domus, the statuettes were placed in a recess of a specific aedicule called larario and, in particular occasions or recurring events, venerated by the lighting of a flame.

Near every domestic heart and home, the Lares Familiars were established, votive aedicule, that kept vigil on the fortune of the house and family, including the slaves from generation to generation.

The ethics of dwelling implies "to be with the others and with himself" in the non-human environment, by the rescue of our distinction and after all of our loneliness. In the way of building, furnishing, and living the place of daily life, man catches the evocative capacity of the nature and puts into practice his abilities, of humanising the world.

Home takes shape a border between inside and outside, often they are psychic conditions rather than physical ones. The space of the sculpture is connected with man who builds his dwelling, a space that is not absolute, but refers to the idea of poetically dwelling the hearth. Over the centuries, in particular at the end of '800, the collocation of tabernacles and their distribution in the architectural and natural landscape is a real "religious sig- nage", that involves places that belong to a topological conception of the space first of all: the holy image has a value of protection, given the conflictual implications involved on the symbolic level the passages among the areas topologically different.

This sacralisation of places and this minor architecture arise mostly from the will of individuals. The votive aedicule, the universe that brings with itself, expresses a rural world (farming, craftsmanship, bucolic), it comes in an extreme simplicity of resources, expression and elaboration, in accordance with basic feelings of biological, magical-religious type, as the anthropologist De Martino mentions. Immediate expressions of faith in therapeutic and comforting virtues of some Saints, a faith in the "prodigious things", a religiousness understood as possibility of free safety, of unexpected intervention of safety or preservation from evil and from death.

These aedicules, are popular as real object, purpose, realization (the subject of tables, the colour, the material used, etc.) the use; they have popular intent in "didactic" sense because they establish a direct relation between worshipper and divinity.

Today the votive aedicules are like consolations of singular points scatter it in historical fabric of Naples, which make urban space sacred, even beyond the immediate meaning of the image and the statues they contain. Regard- less, therefore, of the specificity of the individuals cults, complex and articulated, which changed from case to case (in addition to the saints and the Madonnas, there are also the so called "purgative souls), the aedicules, built for individual initiative, act of aggression factor and further identification of the alley, district, quarter. Between the potentially unknown space - and therefore potentially hostile and threatening- and the need for reassurance, the aedicule performs a mediating function, transforming the realistic space into a protected space. 
Exactly in their dual function, private and public announcement, the conformation and the related ceramics express a simple yet intense religiosity. These are not anachronism but perhaps, if only for the older population still closely linked to their territory, a need the for local communities to affirm a collective identity felt to be threatened by rapid processes of social and cultural change, and the attempt to recover a collective religious dimension.

The votive niche, really managed by the people of the neighborhood, is a point of union of relationships, a place of worship and prayer, a fixed stage for believers and superstitious, it is the conferring of a sacred sense of a place.

\section{The Ponticelli district}

The case study analyzed concerns the Ponticelli district, located in the outskirts of Naples, born by aggregation of urban courtyards, in response to a culture of spontaneity manifested by the inhabitants, mostly farmers, starting from the mid-1800s. The district safeguards numerous votive niches, some ancient, others closer to us in time, some offered in plain sight, others jealously guarded inside entrance halls. Built by private citizens as an act of devotion or as an act of gratitude towards the Saints or the Madonna for a received grace, the votive niches have always been an expression of popular art and religion. Many of these niches, often the oldest, they seem to have been abandoned, reducing themselves to simple plaster folds or bare niches in the masonry, like skeletal orbits that have lost the vividness of the gaze. Gambardella (1984) In this case they participate to the general landscape of the courts, swallowed up in the intense vocabulary that animates volumes and surfaces with exuberance and extraversion. Instead, where we read a very lively care and attention on the part of the inhabitants, we find ourselves faced with interesting signs in which seem to condense archaic mixed emotions and intense feelings linked to the daily stories of families or individuals. The function of the aedicule was, and it is a point of aggregation and reference for the whole neighbourhood as a place of worship to recite the Rosary or simple orations during the day. In the past the votive niches were placed to protect a house or a street and erected by the guilds of trade (coronaries, butchers, gardeners, chairmen etc.) and to women (who were called "madonnare") was entrusted the task of keeping the devotion alive and taking care of the aedicula, of "their" niche with a few flowers or a light. A tradition that continues today. Their value lies in the community's testimony of community's faith and therefore they should be protected beyond their more or less great artistic value. The analyzed newsstands can be divided into three different types: chapel, rib vault and niche.

Those with chapel shape refer to the idea of a small building which, in addition to housing the sacred image that is venerated on the back wall, also includes a small space where a few people can be welcomed and, not infrequently, is also equipped with a small altar.

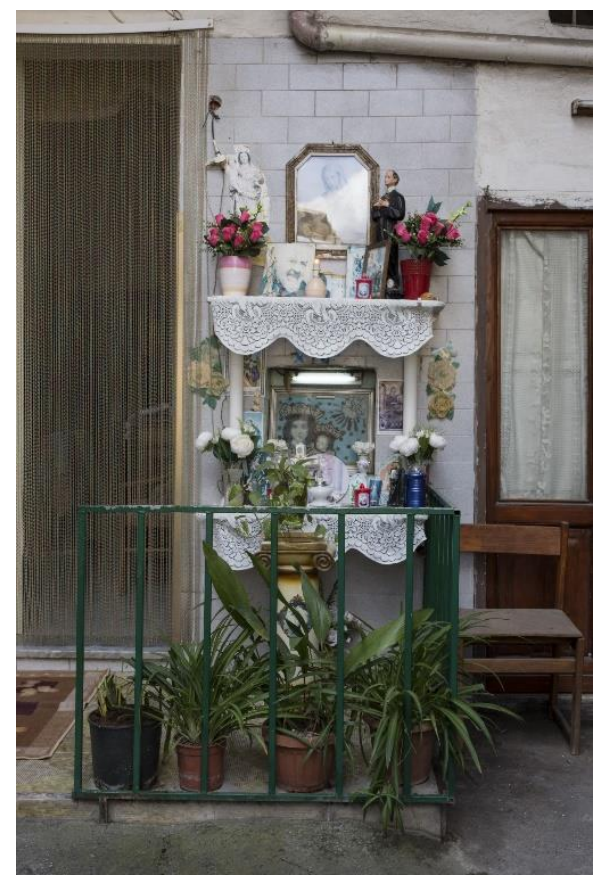

Figure 1. Example of a chapel votive altars in Via Casa Riccardi 


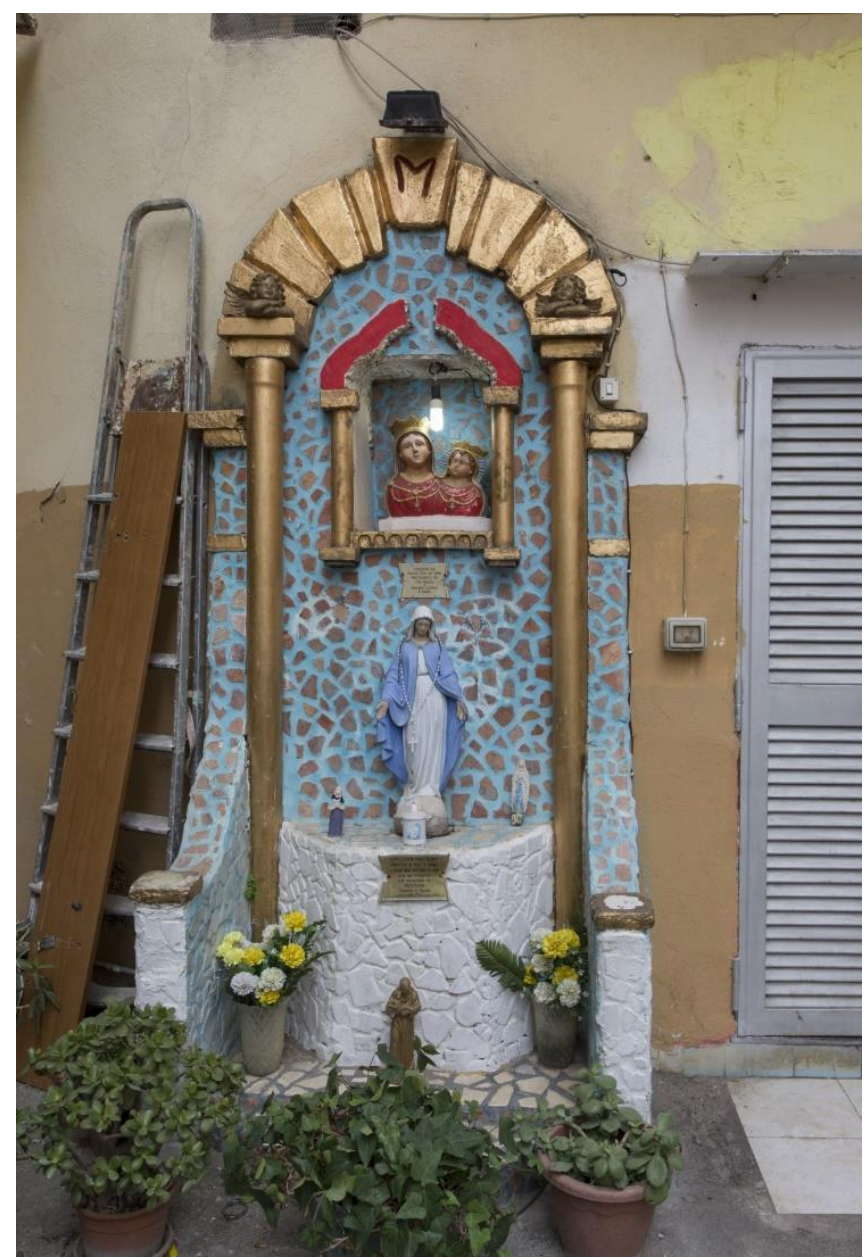

Figure 2. Example of a chapel votive altars in Viale Margherita

While those with vault shape, appear as a construction in its own right, but consisting only of a wall mostly terminating with a crowning tympanum, and in which a small niche is located containing the Sacred image and adorned with decorations.

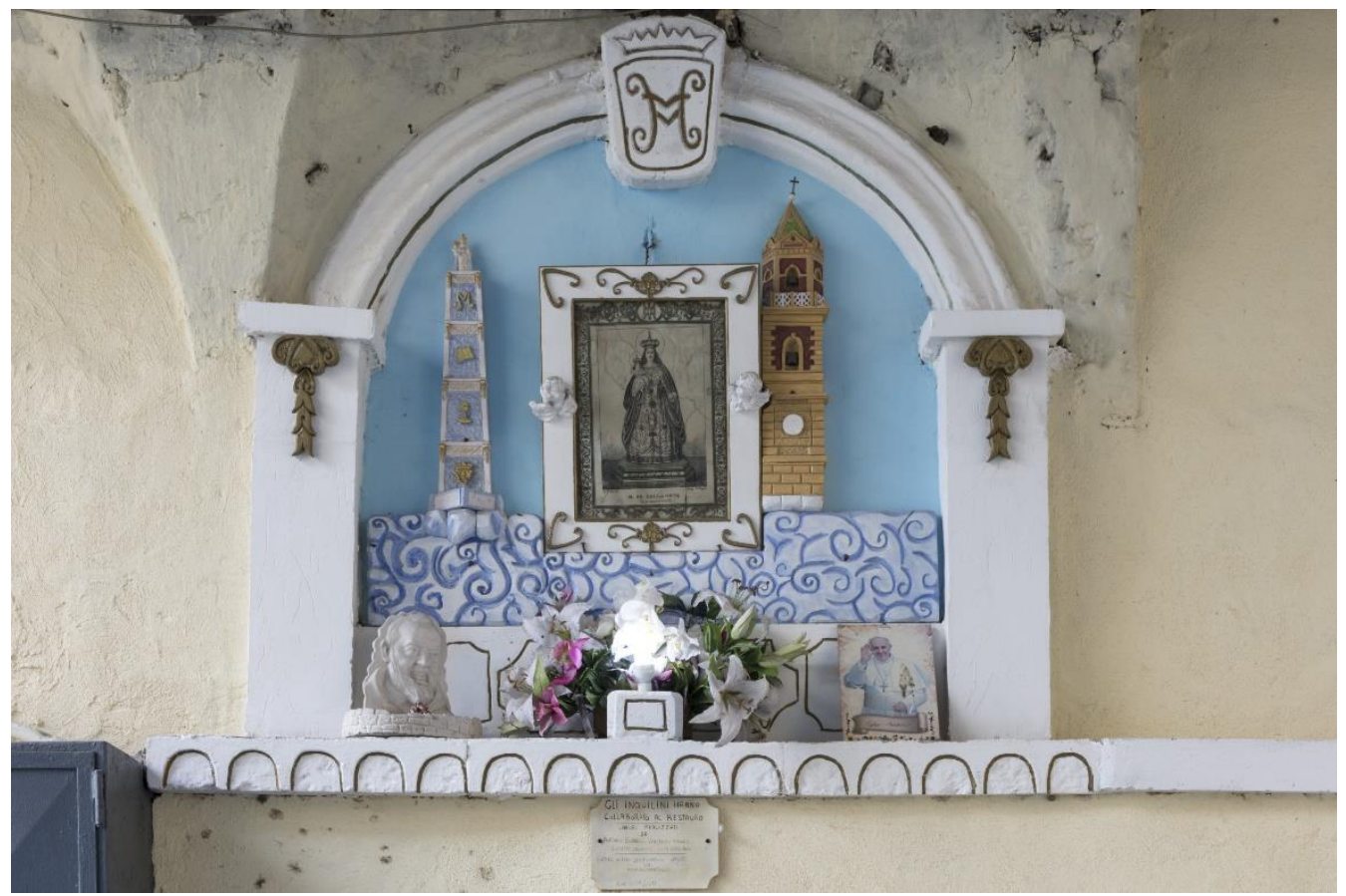

Figure 3. Example of a vault votive altars in Viale Margherita 
Gambardella / Proceedings of Science and Technology

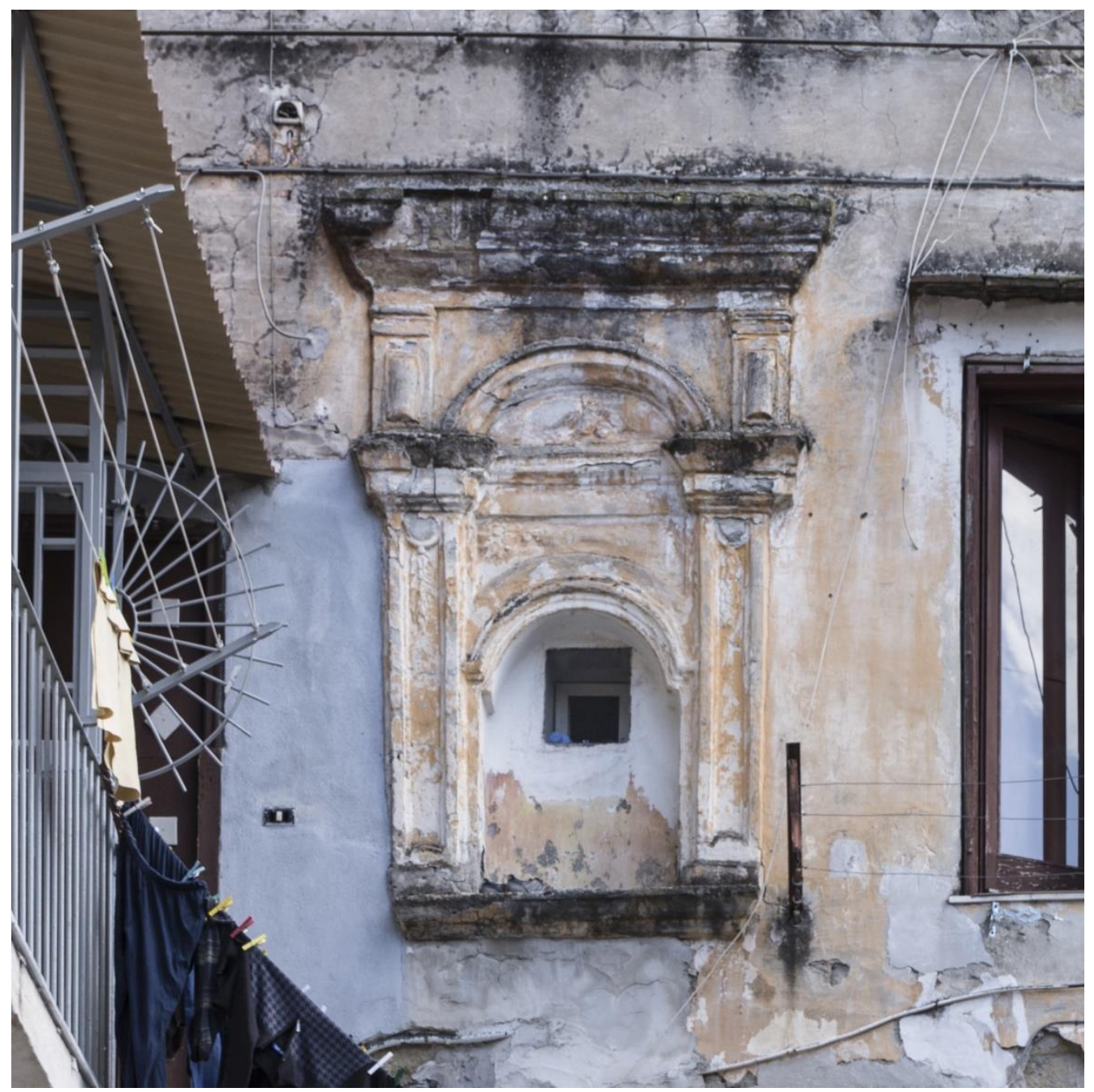

Figure 4. Example of a vault votive altars in Viale Margherita

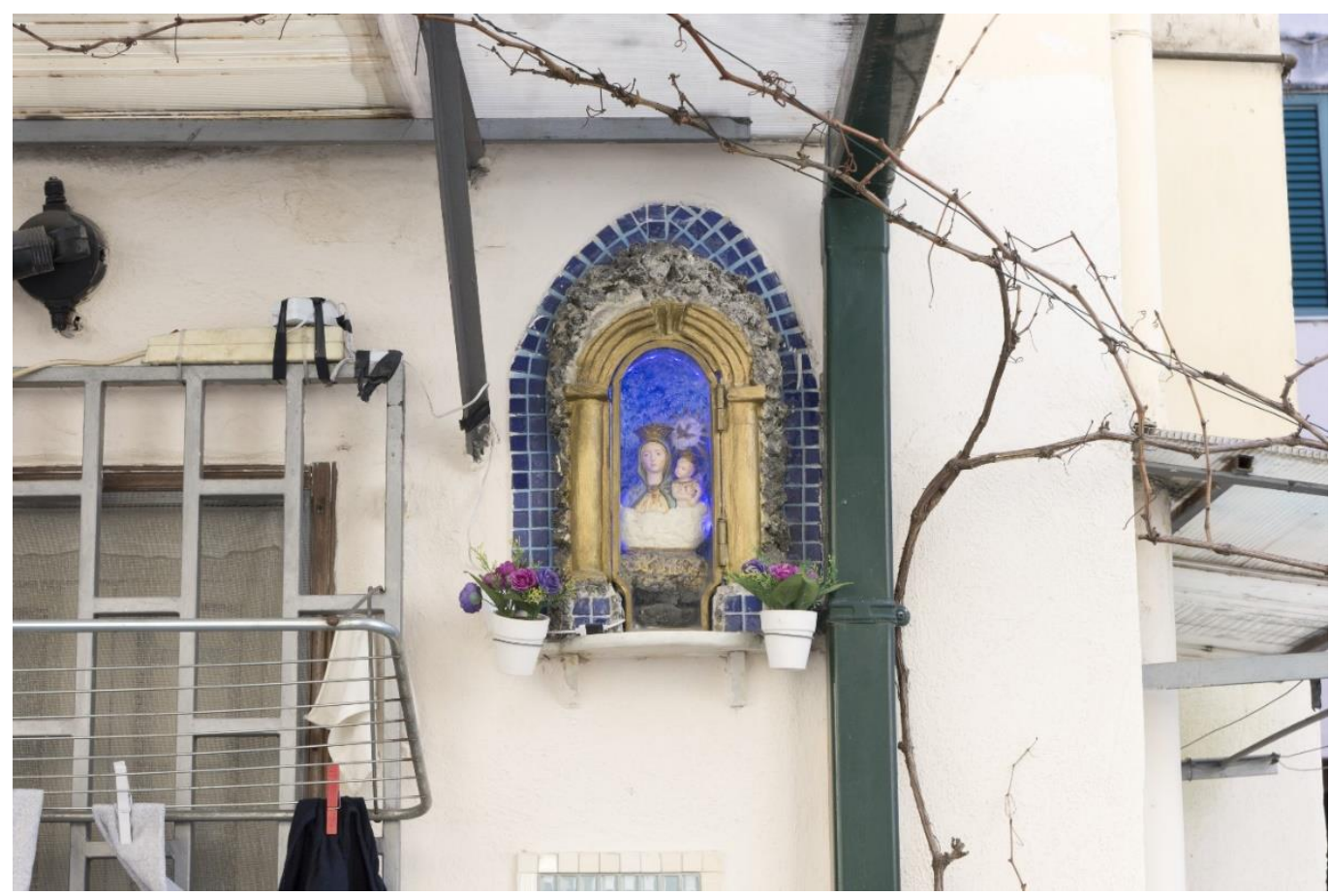

Figure 5. Example of a vault votive altars in Via Cupa sanPietro 
Gambardella / Proceedings of Science and Technology

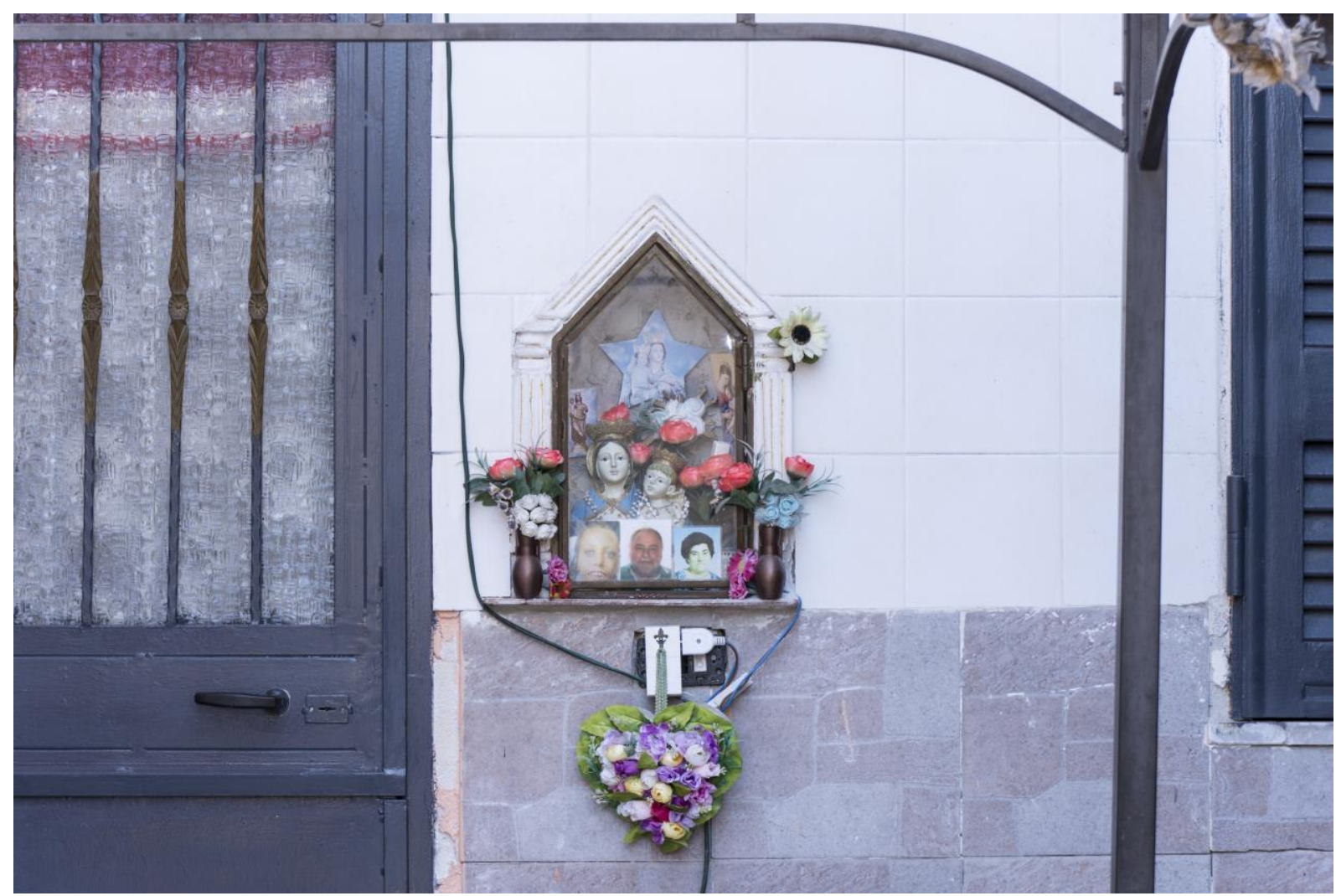

Figure 6. Example of a vault votive altars in Via Cupa sanPietro

Instead, they are defined as niches when they are made through a recess of a niche, which can have different shapes, mostly obtained in walls of houses, but also, along the roads, in walls containing the ground, as still in those of public buildings.

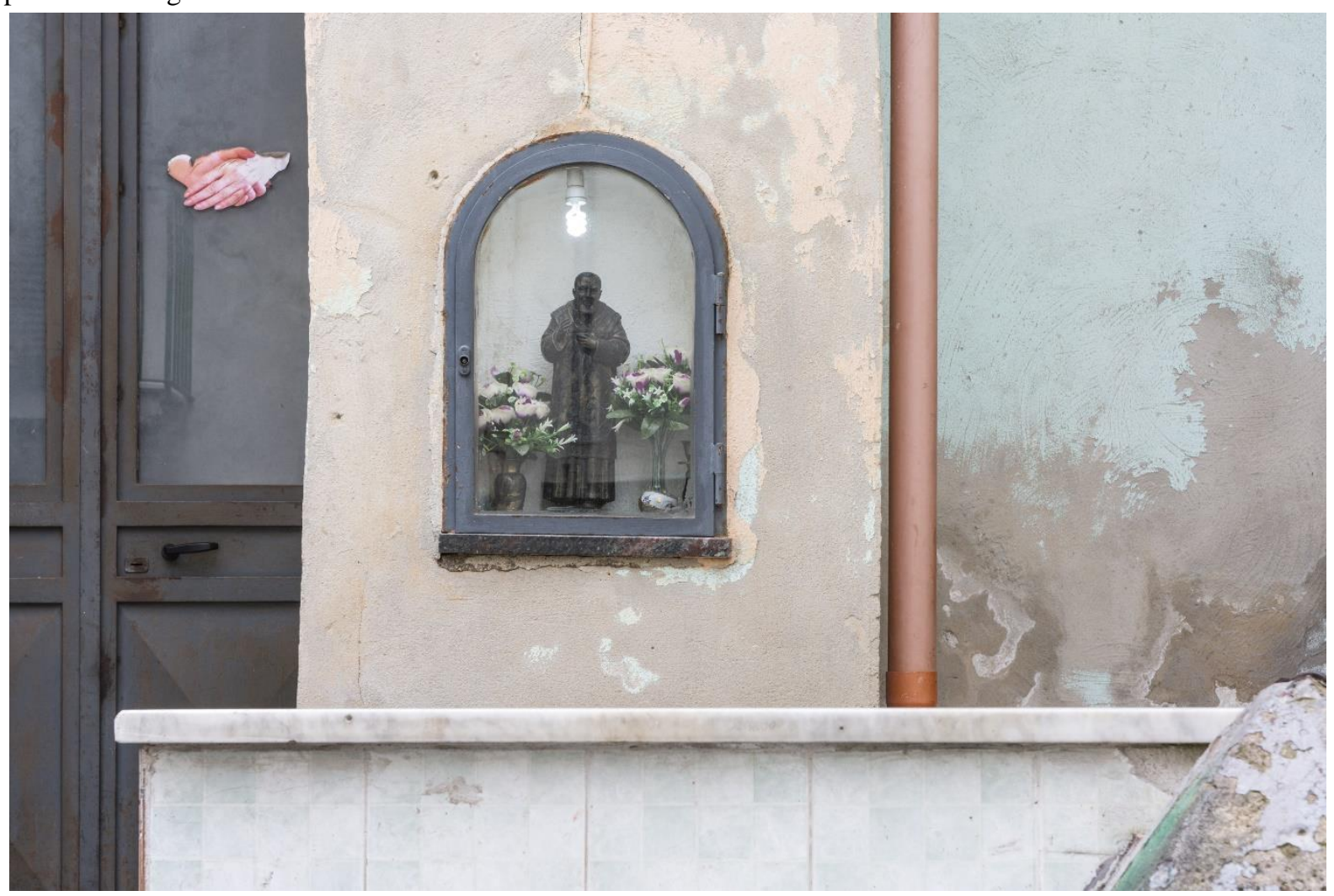

Figure 7. Example of a niches votive altars in Viale Crisconio 


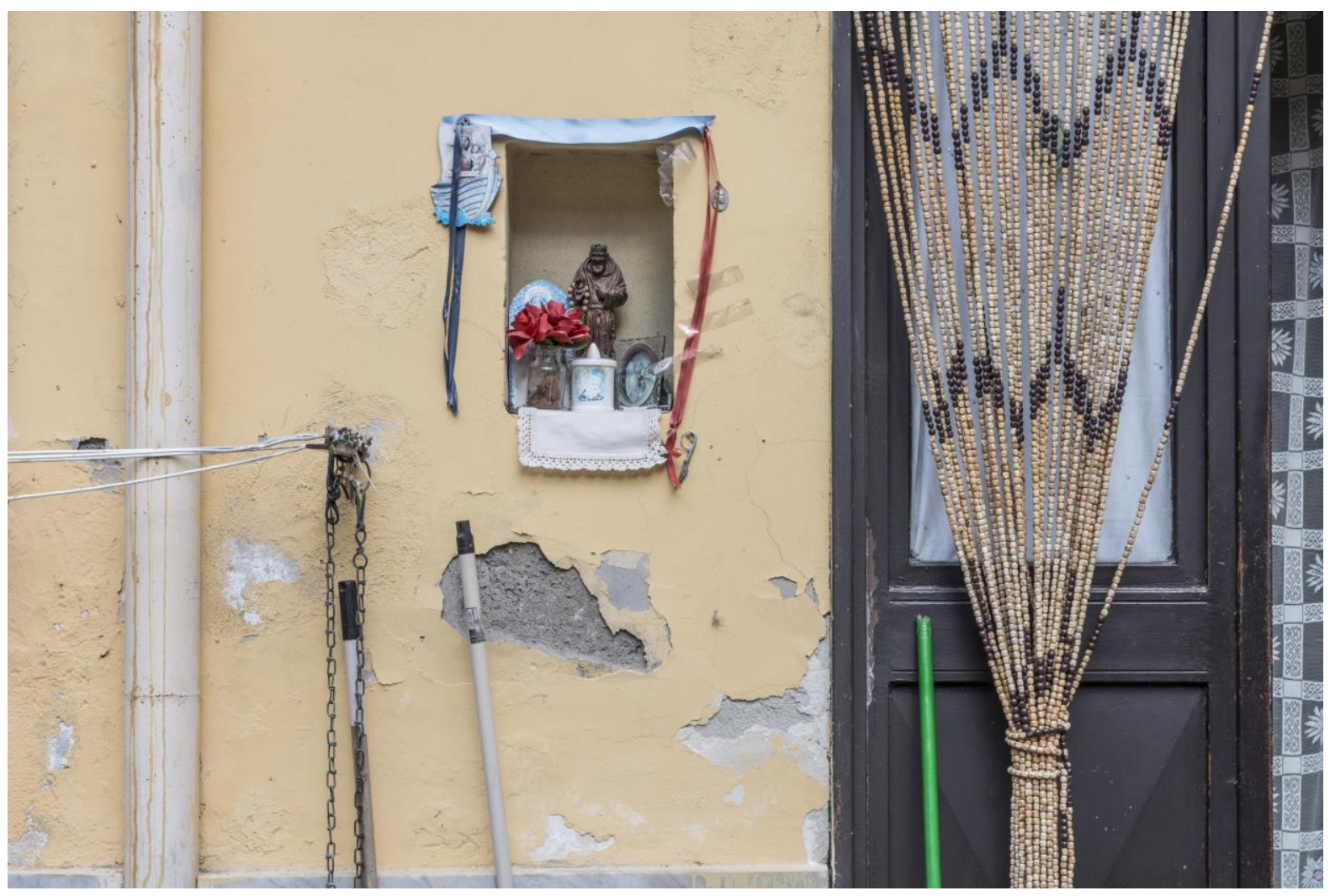

Figure 8. Example of a niches votive altars in Via Casa Riccardi

\section{Conclusion}

The representetions and pictorial techniques, they dominate in the old niches, those executed as a wall painting; in these, even where other more recent images have been placed such as prints or small statuettes, under the 'scialbo' of lime that covers them it is not difficult to see the more or less evident traces of the initial mural painting. The ceramic or terracotta images are more recent, still today, are used in new buildings.There are rarer niches with the sacred image made on canvas or paper, materials that were not appropriate to be placed outside, but in a cappella or sheltered aedicules inside the building. The stucco frames are very interesting, they can be more or less elaborate (with the presence of floral elements, coils, shells) depending on the period in which they were made, but also on the economic availability of their client and of the skill acquired by the plasterers. Immense heritage of culture and history, the niches represent the past and the future in the present and therefore we should think of a real program of protection, recovery and cataloging. Communities should work to preserve them and try to integrate these works into not only religious, but also cultural, architectural paths, so as to highlight the most intimate local values. The research, aimed at cataloging votive niches and inserting them into a path, will lead to the definition of an itinerary, which will highlight their relationship with the buildings, seen in a wider, urban context, and related to the environment as elements to support the charm of the historic center.

\section{References}

De Martino E. (2013). Sud e Magia. Milano: Giacomo Feltrinelli Editore.

Fusco. M. L. \& Saitto V. (2016). La qualita`oikogena dell'architettura - Lo spazio della soglia. Napoli: Edizioni Scientifiche Italiane.

Galimberti, U. (2000). Il bene e il male attraverso il mistero. Milano: Giacomo Feltrinelli Editore. Gambardella, C. (1984). Arredo Urbano a Napoli/Edicole. Milano: DOMUS.

Heidegger, M. (2008). Poeticamente abita l'uomo.Milano. Vitali: Moretti. 